\title{
Maturation of Sucrase-Isomaltase Complex in Human Fetal Small and Large Intestine during Gestation
}

\author{
NICOLE TRIADOU AND ALAIN ZWEIBAUM \\ Unité de Recherches de Génétique Médicale [N.T.], INSERM U 12, Hôpital des Enfants Malades, and Unité de \\ Recherches sur le Métabolisme et la Différenciation des Cellules en Culture [A.Z.], INSERM U 178, Hôpital \\ Broussais, Paris, France
}

\begin{abstract}
Sucrase-isomaltase complex is expressed in human small intestine throughout gestation and in the large intestine between 12 and $30 \mathrm{wk}$. The molecular form of the enzyme was studied in the brush-border membrane fractions by the immunoblotting method. Before $30 \mathrm{wk}$ of gestation, the enzyme is present only as the high molecular weight prosucrase-isomaltase, while from $30 \mathrm{wk}$ until birth the two subunits are also present. The fetal enzyme, as its proform and as its two subunits, has a faster mobility in sodium-dodecylsulfate polyacrylamide gel electrophoresis, than the adult enzyme (removal of sialic acid residues from fetal enzymes emphasizes this difference). The colonic and the small intestinal fetal enzymes are identical. (Pediatr Res 19: 136-138, 1985)
\end{abstract}

Sucrose $\alpha$-D-glucohydrolase complex (EC 3.2.1.48) is the main marker of enterocytic differentiation, and one of the primary intestinal brush-border enzymes (4). Recently it has been shown in mammals to be synthetized as a single chain secondarily split to two subunits by pancreatic proteases $(3,7,13)$. In early human fetal small intestine the enzyme is present as high molecular weight single chain (8), which is split in vitro by pancreatic elastase. This enzyme also is expressed at a lower level in human fetal colonic mucosa between 10 and $30 \mathrm{wk}$. The activity disappears at term and is not expressed in adult colon $(5,15)$. We studied the spontaneous maturation of human fetal small intestinal and colonic sucrase-isomaltase complex throughout gestation, and compared the fetal and adult enzymes.

\section{MATERIALS AND METHODS}

Small intestinal samples $(n=6)$ and colon samples $(n=4)$ from human fetuses between 16 and 39 wk of gestation were obtained after spontaneous or legal therapeutic abortion and stored at $-80^{\circ} \mathrm{C}$ until use. Adult intestinal fragments were obtained from irreversibly brain damaged kidney donors as previously described $(12,15)$.

Purification of sucrase complex and antibodies production. Sucrase-isomaltase from a blood group $\mathrm{O}$ human small intestine was purified as previously described $(10,15)$. Briefly brushborders were digested with papain; the papain supernatant was applied on sequential chromatographic columns including anion exchange chromatography, gel filtration, and Sephadex G 200

Received January 12, 1984; accepted July 27, 1984.

Correspondence Dr. N. Triadou, INSERM U 12, Hopital des Enfants Malades, 75743 Paris, Cedex 15, France. chromatography. The homogeneity of the preparation was assessed by polyacrylamide gel electrophoresis and crossed immunoelectrophoresis against an antihuman brush-border antiserum (12). Rabbits were immunized by sc injections at 15 -day intervals with $0.2 \mathrm{mg}$ of purified enzyme and bled 7 days after the fourth injection. Immunoglobulins $G$ were prepared by ion exchange chromatography $(10,15)$.

Brush-border separation, transfer, and identification of antigen. Preparations of the brush-border fractions of small and large intestine were obtained by the calcium precipitation method as previously described (12). The proteins were separated on polyacrylamide slab gel electrophoresis, with molecular weight markers (myosin: $200 \mathrm{k}, \beta$-galactosidase $116 \mathrm{k}$, phosphorylase b $94 \mathrm{k}$ ). The proteins were then transferred on nitrocellulose sheets as previously described (11). The nitrocellulose, after 60 min incubation in a phosphate buffered saline solution pH 8.0 containig $10 \%$ bovine serum albumine (buffer $\mathrm{A}$ ), was immersed in sucrase-isomaltase antibodies diluted in buffer $\mathrm{A}$, then in peroxidase-labeled antirabbit immunoglobulins (Institut Pasteur, Paris). Peroxidase was revealed with diaminobenzidine $(0.05 \%)$ and hydrogen-peroxide $(10,11,15)$.

Enzymatic and proteins determinations were as previously described (12). Specific activities are expressed in units/g protein. The paucity of human fetuses samples did not allow us in most cases, to repeat the enzymatic determinations.

Neuraminidase treatment of brush-border fractions. Sixty micrograms of brush-border proteins were incubated for $3 \mathrm{~h}$ at $37^{\circ}$ $\mathrm{C}$ with $7.2 \mathrm{mU}$ neuraminidase (Type $\mathrm{V}$, Sigma) in $50 \mathrm{mM}$ acetate $10 \mathrm{mM} \mathrm{CaCl}$ buffer $\mathrm{pH}$ 5.6. Neuraminidase treated brush-borders were then separated as described.

\section{RESULTS AND DISCUSSION}

The enzymatic specific activities of sucrase in small intestinal and colonic samples are shown on Table 1. They are in good accordance with previous reported values for fetal intestine $(5$, 8,15 ). For the 15-, 18-, and 24-wk samples, the results were obtained from homogenate of the whole intestinal mucosa, and we observed a progressive rise in activity between 15 and 24 wk; at $24 \mathrm{wk}$ the activity was near adults values. For the 16-, 30-, and 39-wk samples, only small pieces of intestine, not precisely localized, were obtained. The 30-wk fetus was less well conserved that the other fetuses, and this could explain the discrepancy obtained in the specific activities. These brush-border activities are enriched 10-15 times as compared to the homogenates, as usually described for sucrase enrichment, assuming that the calcium precipitation method is also useful for brush-border preparation of fetal small and large intestine.

The molecular form of sucrase-isomaltase complex, as detected 
by tie immunoblotting method, is shown on Figure 1. Before 30 wk of gestation the enzyme is expressed only as the high molecular weight form (small intestines of $15,16,18$, and $24 \mathrm{wk}$ and 24 wk colon), as was described by Skovbjerg (8). At 30 wk and at term the complex is in part split into its two subunits, sucrase and isomaltase, of lower molecular weight. These two subunits have very similar properties, and in most cases, particularly in the adult intestine, cannot be separated into two distinct bands. Rather, there is a broad band at about 150000 daltons. Small intestinal and colonic forms behave similarly, except that the expression of the colonic enzyme is lower than in the small intestine between 15 and $30 \mathrm{wk}$ and decreases from $30 \mathrm{wk}$ until birth, when it is no longer detectable. This cleavage occurs in parallel with the appearance of enterokinase activity in fetal intestinal mucosa at about $26 \mathrm{wk}$ of gestation (1); enterokinase allows the activation of pancreatic proteases into their mature form, and pancreatic proteases have been shown to be responsible for sucrase-isomaltase cleavage $(3,7,8)$.

The fetal form migrates slightly faster than the adult enzyme in sodiumdodecylsulfate polyacrylamide gel (Figs. 2 and 3). The proform at every stage of gestation, and the two subunits when the cleavage occurs, have both a faster anodal mobility as compared to the adult forms. These differences may be due either to

Table 1. Specific activity of sucrase enzyme in the brush-border fraction of different small intestinal and colonic samples (units $/ g$ protein)

\begin{tabular}{lcc}
\hline Gestational age & Small intestine & Colon \\
\hline $15 \mathrm{wk}(n=1)$ & 293 & 65 \\
$16 \mathrm{wk}(n=1)$ & 435 & \\
$18 \mathrm{wk}(n=1)$ & 663 & \\
$24 \mathrm{wk}(n=1)$ & 1121 & 193 \\
$30 \mathrm{wk}(n=3)$ & $278 \pm 91 \dagger$ & 39 \\
$39 \mathrm{wk}(n=3)$ & $765 \pm 174 \dagger$ & 4 \\
Adult $(n=5)$ & $1526 \pm 298 \dagger$ & 1 \\
\hline
\end{tabular}

* Number of determinations.

$\dagger$ Mean \pm SEM.

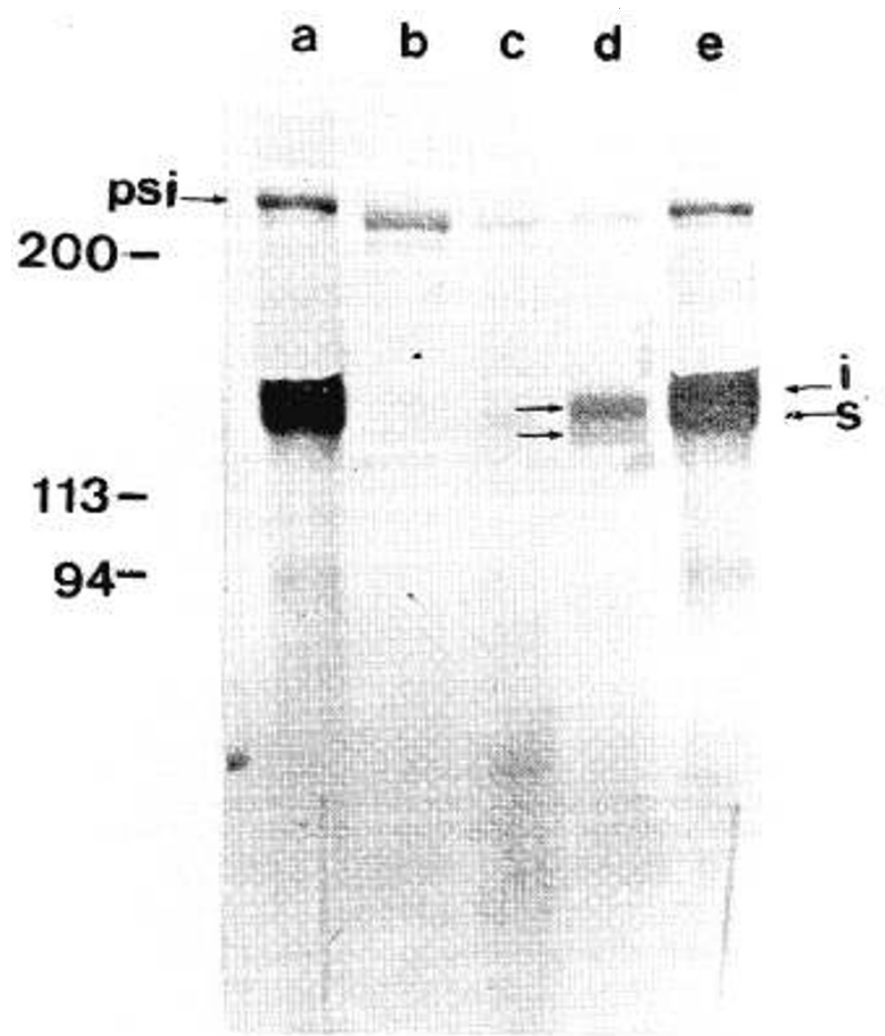

Fig. 2. Sucrase-isomaltase of fetal small intestine samples, separated on $6.5 \%$ polyacrylamide slab gels, and detected by immunoblot. $a, e$, adult jejunum; $b, 15 \mathrm{wk} ; c, 30 \mathrm{wk} ; d, 39 \mathrm{wk} ; p s i$, prosucrase-isomaltase; $i$, isomaltase subunit; $s$, sucrase subunit. In $c$ the low amount of residual material available did not allow to deposit a sufficient amount of proteins, which explain the differences of intensity as compared to Figure $1 c ; 200$, 113 , and 94 arrows correspond to the migration of molecular weight markers (see "Materials and Methods").

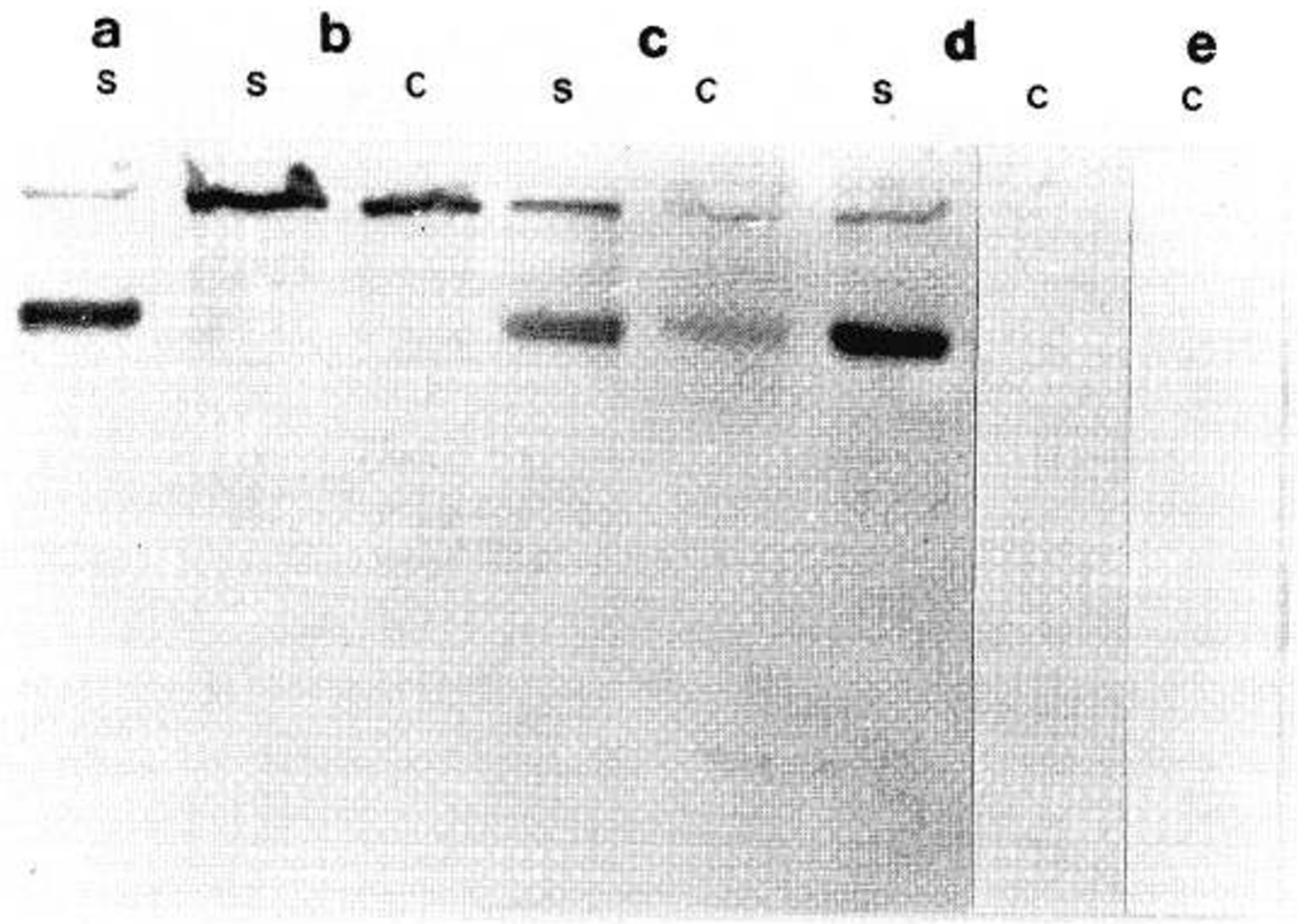

Fig. 1. Immunoblotting detection of sucrase-isomaltase in different brush-border samples (proteins, $60 \mu$, were separated in $8 \%$ acrylamide slab gels) $a$, adult; $b, 15 \mathrm{wk} ; c, 30 \mathrm{wk} ; d, 39 \mathrm{wk} ; e$, adult; $s$, small intestine; $c$, colon. 


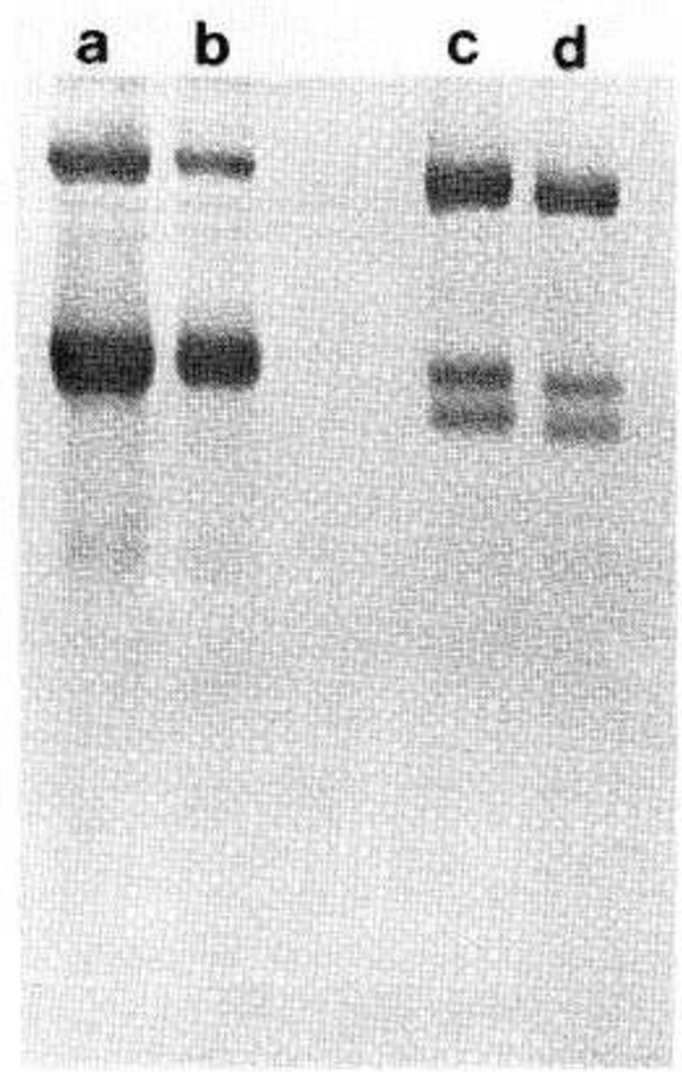

Fig. 3. Neuraminidase treated sucrase-isomaltase, detected by immunoblot. $a$, control adult sucrase; $b$, neuraminidase-treated adult sucrase; $c$, control 30 wk fetal sucrase; $d$, neuraminidase-treated fetal sucrase.

a difference in the polypeptide chain expression of a fetal gene, as described for instance for myosin (14) or hemoglobin (9), or to differences in the glycosylated part of the molecules. Fetal intestinal alkaline phosphatase has a different electrophoretic mobility than the adult enzyme, which disappears after neuraminidase treatment (6). Preliminary results of analysis of meconial brush-border enzymes have shown a modified affinity for Concanavalin A (2). Neuraminidase treatment of the brushborder fraction of the 30-wk fetus showed (Fig. 3) that sialic acid is present on the fetal sucrase-isomaltase, and not on the adult enzyme. The migration of adult enzyme is not modified by neuraminidase treatment, while the fetal enzyme (the prosucraseisomaltase and its two subunits clearly separated in the fetal intestine) migrates further. Thus the adult and fetal enzyme are different; this difference is not only due to sialic acid, because the migration of fetal enzyme is more rapid after removal of sialic acid molecules. These differences are present on the precursor and on the two subunits, and are thus independent of the cleavage process. The time of the switch remains to be determined, at birth or after birth.

Acknowledgments. We thank Mrs. E. Audran for excellent technical assistance and Miss C. Dalleu for typing the manuscript.

\section{REFERENCES}

1. Antonowicz I, Lebenthal E 1977 Developmental pattern of small intestinal enterokinase and disaccharidase activities in the human fetus. Gastroenterology $72: 1299$

2. Auricchio S, Caporale C, Santamaria F 1981 Human fetal intestinal brushborder sucrase, oligoaminopeptidase and dipeptidylaminopepdidase. Pediatr Res 15:1193

3. Hauri HP, Quaroni A, Isselbacher KJ 1979 Biogenesis of intestinal plasma membrane: post translational route and cleavage of sucrase-isomaltase. Proc Natl Acad Sci USA 76:5183

4. Kenny, AJ, Maroux S 1982 Topology of microvillar membrane hydrolases of kidney and intestine. Physiol Rev 62:91

5. Lacroix B, Kedinger M, Simon-Assmann P, Rousset M, Zweibaum A, Haffen K 1984 Developmental pattern of brush-border enzymes in the human fetal colon. Correlation with some morphogenetic events. Early Hum Dev 9:95

6. Mulivor RA, Hanning VL, Harris H 1978 Developmental change in human intestinal alkaline phosphatase. Proc Natl Acad Sci USA 75:3909

7. Sjöstrom H, Noren O, Christiansen L, Wacker H, Semenza G 1980 A fully active, two active-site, single-chain sucrase-isomaltase from pig small intestine. J Biol Chem 255:1132

8. Skovbjerg H 1982 High molecular weight prosucrase-isomaltase in human fetal intestine. Pediatr Res 16:948

9. Stamatoyannopoulos G, Nienhuis AW 1979 Cellular and Molecular Regulation of Hemoglobin Switching. New York, Grune and Stratton

10. Triadou N: Antigenic cross-reactions among human intestinal brush-border enzymes revealed by the immunoblotting method and rabbit anti-enzyme sera. J Immunol Methods, in press

11. Triadou N, Audran E, Rousset M, Zweibaum A, Oriol R 1983 Relationship between the secretor status and the expression of $\mathrm{ABH}$ blood group antigenic determinants in human intestinal brush-border membrane hydrolases. Biochim Biophys Acta 761:231

12. Triadou N, Bataille J, Schmitz J 1983 Longitudinal study of the human intestinal brush-border membrane proteins. Distribution of the main disaccharidases and peptidases. Gastroenterology 85:1326

13. Wacker H, Jaussi R, Sonderegger P, Dokow M, Ghersa P, Hauri HP, Christen $P$, Semenza $G 1981$ Cell free synthesis of the one-chain precursor of a major intrinsic protein complex of the small intestinal brush-border membrane (prosucrase-isomaltase). FEBS Lett 136:329

14. Whalen RG, Butler-Browne GS, Sell S, Gros F 1979 Transitions in contractile protein isozymes during muscle cell differentiation. Biochimie 61:625

15. Zweibaum A, Triadou N, Kedinger M, Augeron C, Robine-Leon S, Pinto M, Rousset M, Haffen K 1983 Sucrase-isomaltase: a marker of fetal and malignant epithelial cells of the human colon. Int J Cancer 32:407 